\title{
Converting Tsunami Wave Heights to Earthquake Magnitudes
}

\author{
Nils-Axel Mörner \\ Paleogeophysics \& Geodynamics, Stockholm, Sweden \\ Email: morner@pog.nu
}

How to cite this paper: Mörner, N.-A (2017) Converting Tsunami Wave Heights to Earthquake Magnitudes. Open Journal of Earthquake Research, 6, 89-97. https://doi.org/10.4236/ojer.2017.62005

Received: April 24, 2017

Accepted: May 12, 2017

Published: May 15, 2017

Copyright (C) 2017 by author and Scientific Research Publishing Inc. This work is licensed under the Creative Commons Attribution International License (CC BY 4.0).

http://creativecommons.org/licenses/by/4.0/

\section{cC) Open Access}

\begin{abstract}
There is a fairly strict relation between maximum tsunami wave heights and causation earthquake magnitudes. This provides a new tool for estimating the magnitude of past earthquakes from the observed wave heights of related paleo-tsunami events. The method is subjected to a test versus two paleoseismic events with multiple independent estimates of corresponding earthquake magnitude. The agreement to the tsunami wave height conversion is good, confirming very high magnitudes of M 8.5 - 9.0 and M 8.4 - 8.5. Applying the same method to two Late Holocene events of methane venting tectonics indicates a ground shaking of forces equivalent to a M 8.0 earthquake, seriously changing previous long-term crustal hazard assessments.
\end{abstract}

\section{Keywords}

Tsunamis, Wave Height, Earthquakes, Magnitudes, Paleo-Tsunamis, Methane Venting Tectonics, Hazard Assessment

\section{Introduction}

Major tsunami events are primarily generated by submarine earthquakes [1] [2]. In principle, there is a relation between earthquake magnitude and tsunami wave height. During the last 13 years, there has been eight high-amplitude tsunami wave events |3]; viz. 1) the 2004 Indian Ocean event with a tsunami wave height of $20 \mathrm{~m}$ (a statement of a $30 \mathrm{~m}$ height is considered to represent a run-up height, not an actual wave height) and a Mw 9.1 earthquake magnitude, 2) the Java 2006 event with a wave height of $8.6 \mathrm{~m}$ and a magnitude of $\mathrm{Mw} 7.7,3)$ the Benkula 2007 event with a wave height of $1.65 \mathrm{~m}$ and a magnitude of $\mathrm{Mw} 8.5,4)$ the Peru 2007 event with a wave height of $3-4 \mathrm{~m}$ and a magnitude of Mw 8.0,5) the Samoa 2009 event with a wave height of $11.9 \mathrm{~m}$ and a magnitude of $\mathrm{Mw} 8.1,6$ ) the Mentawai 2010 event with a wave height of $10 \mathrm{~m}$ and a magnitude of Mw 7.7,7) the Chile 2010 event with a wave height of $17.2 \mathrm{~m}$ and a magnitude of Mw 8.8 
and 8) the Tihoku-oki 2011 event with a wave height of $19.5 \mathrm{~m}$ and a magnitude of Mw 9.0. Because these 8 events are known both to tsunami wave height and causation earthquake magnitude, they can be used to establish the relationship between tsunami wave height and seismic magnitude [3] [4]. This is illustrated in Figure 1 (modified from [4]). Events 3 and 4 obviously never reached a maximum wave height, and are excluded in establishing the red line relation. Value $1 \mathrm{a}$ is superseded by the better $1 \mathrm{~b}$ value.

\section{Paleo-Tsunamis}

Paleo-tsunamis can rarely be evaluated with respect to earthquake magnitudes [5] [6] [7] [8]. Having established the tsunami height/seismic magnitude relation in Figure 1, we now have a new tool for estimating the corresponding earthquake magnitudes [4].

Even the reverse may apply; i.e. knowing the seismic magnitude of a paleoseismic event, one may estimate the maximum tsunami height. This is the case with the Crete AD 365 paleoseismic event; its magnitude has been estimated to "at least 8.5" [6] or "8.3 - 8.5" [7]. It set up a major tsunami, which hit and destroyed the Library at Alexandria, destroyed 50,000 homes, and killed about 5000 persons [7]. It also left a "mega-turbidite" [7]. The tsunami height is less well known. From Figure 1, it is easy to read that an Mw 8.5 earthquake may set up a tsunami with a maximum wave height of about $15 \mathrm{~m}$. This seems to fit well with observed records [7].

Today Sweden is an area of low to moderately low seismic activity. Due to the very high rate of glacial isostatic uplift at the time of deglaciation it was, at that time, an area of very high paleoseismic activity in frequency as well as in magni-

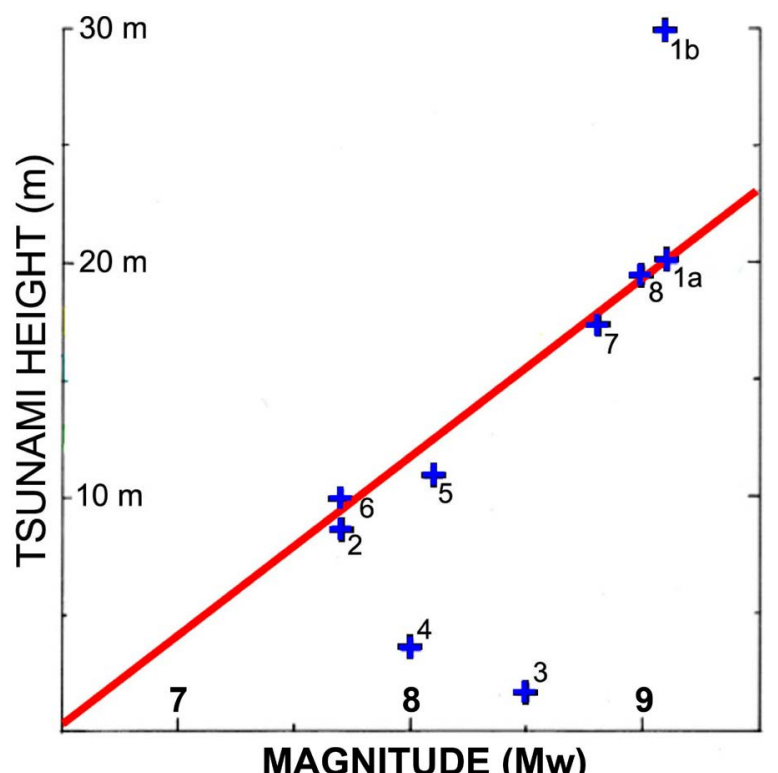

Figure 1. Relation between observed maximum tsunami heights and magnitudes of causational earthquakes (events 1 - 8). Having established this relation, observed tsunami heights of paleoseismic events can be converted to corresponding earthquake magnitudes [4]. The red line gives a ratio of $0.133 \mathrm{Mw}$ per $1.0 \mathrm{~m}$ tsunami wave height. 


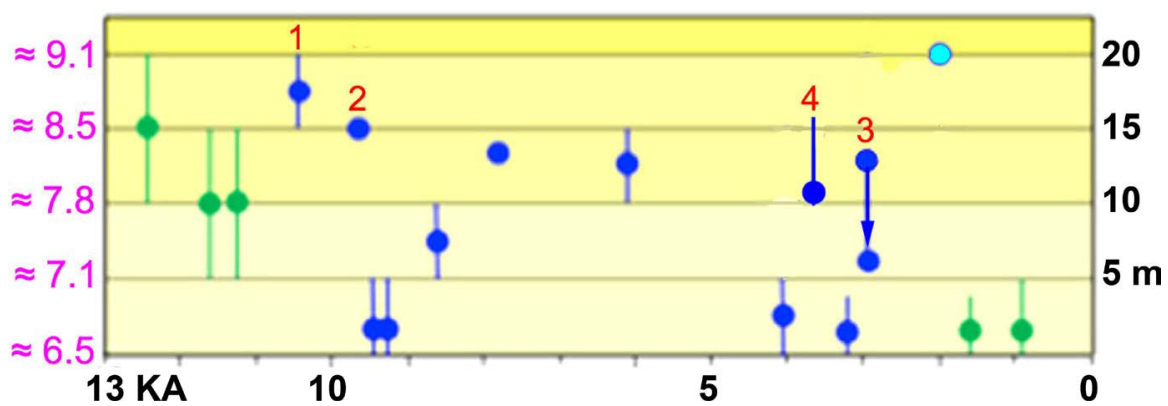

Figure 2. The Swedish paleoseismic database [10] [11] includes 17 tsunami events [4] [14]; 5 in the Kattegatt Sea (green) and 12 in the Baltic (blue) plotted chronologically with respect to observed wave heights. Purple figures to the left give corresponding earthquake magnitudes as read from Figure 1 relation (modified from [4]). The four events further discussed in section 3 are marked in red (1 - 4).

tude [8]-[13]. In total, 62 paleoseismic events have been documented [13], out of which 17 events generated tsunamis [5] [11] [12] [13] [14].

In Figure 2, the Swedish database of tsunami events and wave heights is converted to magnitudes using Figure 1 relations.

Figure 2 demonstrates that the corresponding paleoseismic event must have been of considerable magnitudes (viz. 7 between M 6.5 - 7.5, 6 between M 7.6 8.4, and 3 of $M>8.4$ ). In some of the events ( 1 and 2 in Figure 2), there are independent magnitude estimates from liquefaction, fault movements and bedrock deformation [8] [10] [11], which can be used for testing the relations among wave heights and magnitudes as given in Figure 1.

\section{Application on Some Swedish Paleo-Tsunami Events}

The first Paleoseismic Catalogue of Sweden [10] included 52 paleoseismic events, and the second Paleoseismic Catalogue 62 events [11]. All events entering the catalogues were documented by multiple criteria [8] [10] [11] and well dated; often by varve chronology with an annual resolution [10] [13] (varve ages are assigned $\mathrm{vBP}$, for distinction to conventional C14-dates in $\mathrm{BP}$ ). All the events in the catalogues were assigned a magnitude estimate [10] [11], based on a number of different criteria [5].

Two of the Swedish paleoseismic events will be analyzed as a test of Figure 1 tsunami/magnitude relations in comparison with independent estimates based on other criteria presented in [5] [8] [10] and [11].

\subsection{The 10,430 vBP Paleoseismic Event}

Stockholm is traversed by an old Permian fault that extends in west-east direction for about $400 \mathrm{~km}$, and which may continue into the Bay of Finland and Lake Ladoga for another $300-400 \mathrm{~km}$. The fault was reactivated in deglacial time some 10,500 - 10,400 vBP. The frequency of paleoseismic events was very high with 7 independent events recorded and dated with in 102 varve years from 10,490 to 10,388 vBP [8].

In varve year 10,430 vBP a giant earthquake occurred [10]. A lateral to sym- 
pathetic fault located $1 \mathrm{~km}$ north of the main fault was displaced by $6-8 \mathrm{~m}$, indicating a very high magnitude of the causation earthquake. Heavy bedrock fracturing is documented over an area of $50 \times 100 \mathrm{~km}$. Liquefaction has been recorded over an area of $320 \mathrm{~km}$, which is indicative of an earthquake magnitude of about M 9.1 [5] [10] [11]. Liquefaction of gravel is another indicator of a very high magnitude event. An intra-varve turbidite is recorded over an area of $200 \times$ $320 \mathrm{~km}$. Magnetic grain rotation is recorded over an area of $500 \times 600 \mathrm{~km}$ [10] [15]. At present we have no means of converting this value into a magnitude estimate. One thing is clear, however, the magnitude must have been very high, i.e. $\gg 8[5][8]$.

This event also set up a gigantic tsunami event, which invaded several lake basins and washed the strait across southern Sweden (the so-called Närke Straight) free of pack-ice and ice-bergs so that entire Baltic became marine (the Yoldia Stage) within one year [10] [12] [16]. The tsunami wave must have had a wave height of $15-20 \mathrm{~m}$.

In Figure 3, we compare the magnitude estimated from the observed tsunami wave height, with the estimates obtained previously on the bases of other criteria [5] [8] [10] [11].

In principle, there is a very good agreement between all the different and independent means of estimating seismic magnitude. No doubt, the 10,430 vBP paleoseismic event was a very strong event of a magnitude of about M 8.5 - 9.0, which implies that it was a "mega-earthquake". It also means that the test of the

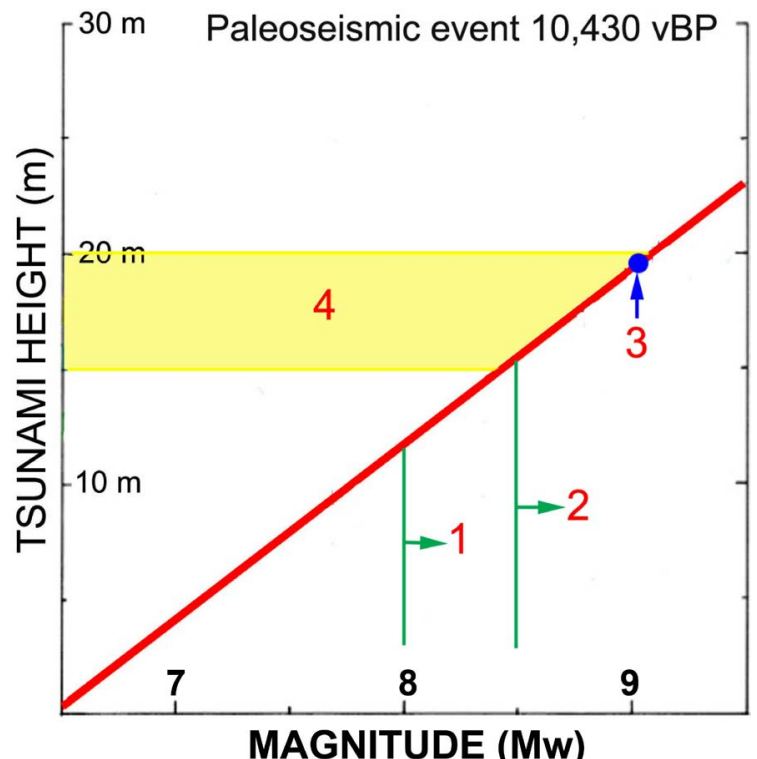

Figure 3. Comparision between previous magnitude estimates (1 - 3) and the present one (4) obtained via the tsunami wave height and earthquake magnitude relation in Figure 1. Group 1 refers to $M>8$ suggested by liquefaction of gravel, fracturing opening of $10-20$ $\mathrm{cm}$, and turbidite spread. Group 2 refers to $M \gg 8$ suggested by $6-8 \mathrm{~m}$ lateral fault displavement $1 \mathrm{~km}$ away from the main fault, spatial distribution of bedrock fracturing, seismic recurrence frequence, and rotation of magnetic grains over an immense area. Point 3 refers to the magnitude $(M \sim 9.0)$ obtained from the spatial distribution of liquefaction. Point 4 represents the magnitude (M 8.5 - 9.0) converted from the tsunami height. 
tsunami vs. magnitude relation of Figure 1 seems to work very well.

\subsection{The 9663 vBP Paleoseismic Event}

This paleoseismic event is known as the Hudiksvall or Iggesund paleoseismic event [10]. It occurred in varve $9663 \mathrm{vBP}$ (or 9150 C14-years BP). It is one of the ever best investigated paleoseismic events [10], documented by primary fault, bedrock deformations over an area of $50 \times 50 \mathrm{~km}$ (with 49 sites investigated in details), recorded and dated in 31 varve sequences with a distinct turbidite extending for $320 \mathrm{~km}$ along the coast, recorded by liquefaction in 15 sited over an area of $40 \times 80 \mathrm{~km}$, and documented as a tsunami event in 14 lakes (and 43 sediment cores) covering an area of $30 \times 125 \mathrm{~km}$. At two sites $35 \mathrm{~km}$ apart, the liquefaction event is composed of 5 different phases, interpreted as shock and after-shock signals, which calls for a very strong event [5] [8] [10] [11].

The tsunami wave height can be very closely fixed at a minimum of $15 \mathrm{~m}$ [10] [12] [14], providing a magnitude of about M 8.5 according to Figure 1 relation $[5]$.

The various independent means of estimating seismic magnitude are compared in Figure 4 to test the new tsunami vs. magnitude relation, and to provide a combined estimate of the corresponding magnitude.

Even for this event, there is a reasonably good agreement between all the different and independent means of estimating seismic magnitude. No doubt, the 9663 vBP paleoseismic event was a very strong event of a magnitude of about $M$

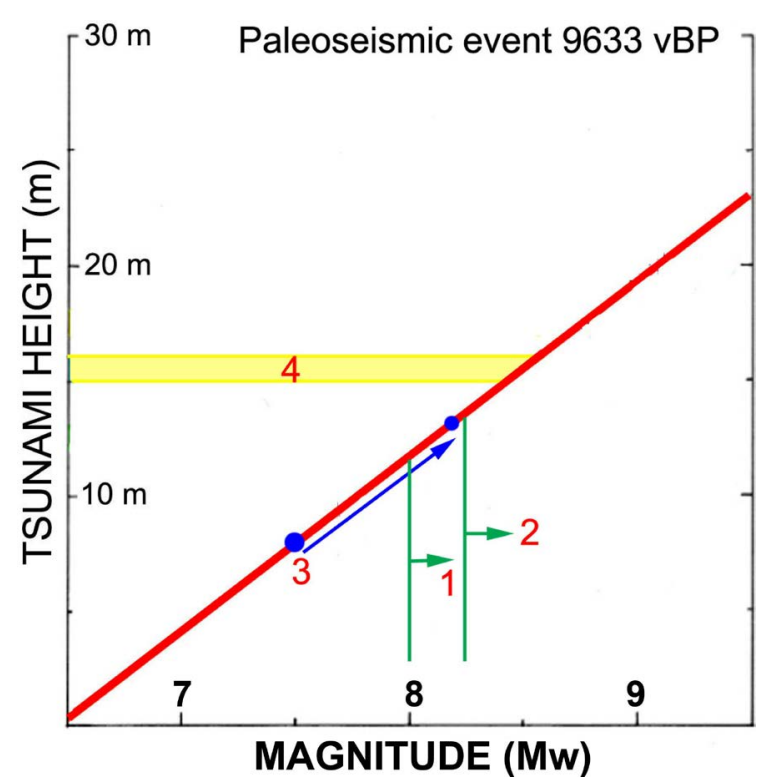

Figure 4. Comparison between previous magnitude estimates $(1-3)$ and the present one (4) obtained via the tsunami wave height and earthquake magnitude relation in Figure 1. Group 1 refers to $M>8$ suggested primary fault displacement, mode of bedrock deformations, slide volumes, spatial distribution of turbidities, liquefaction of gravel, and methane venting. Group 2 refers to $M \gg 8$ suggested by spatial distribution of bedrock deformation, and mode of liquefaction in 5 phases. Point 3 refers to spatial distribution of liquefaction. Point 4 represents the magnitude (M 8.5 - 8.6) converted from the tsunami height. 
8.4 - 8.5. The test of the tsunami vs. magnitude relation of Figure 1 seems to work very well.

\subsection{The 2900 BP Methane Venting Tectonics Event}

Methane venting tectonics is a novel factor, which it has taken time to evolve from the first idea [17] [18] [19] to observational confirmation [10] and finally to full presentation [20] [21], summarized in [22]. It implies the sudden phase transition from methane hydrate stored in voids and fractures in the bedrock to methane gas venting explosively to the surface, by that causing severe bedrock deformation.

This event set up a major tsunami, recorded in nearby bogs and lakes [10] [12]. It was later found to be coincidental with a tsunami event recorded $160 \mathrm{~km}$ to the south [4] [14] with an age of 2900 C14-years BP. At the nearby sites the tsunami wave must have had a height of at least $12 \mathrm{~m}$, and at southern sites a height of at least $6 \mathrm{~m}$. At both sites, the wave had a submarine trimming depth of at least $18 \mathrm{~m}$.

The bedrock is severely deformed in a huge cone of angular block torn out of the bedrock beneath. The cone is $20-25 \mathrm{~m}$ high and $100 \times 150 \mathrm{~m}$ wide (i.e. elliptic). It is surrounded by a depression (compensating the rock masses of the cone). At the top of the cone, there are gigantic blocks of $10 \mathrm{~m}$ to $>10 \mathrm{~m}$ diameters.

Methane venting tectonics is, of course, something quite different from earthquake deformational magnitudes. The deformation was so violent, however, that it was compared to a magnitude $M \sim 7$ earthquake event [10] [11].

In Figure 5 the original magnitude estimate is compared to the magnitude es-

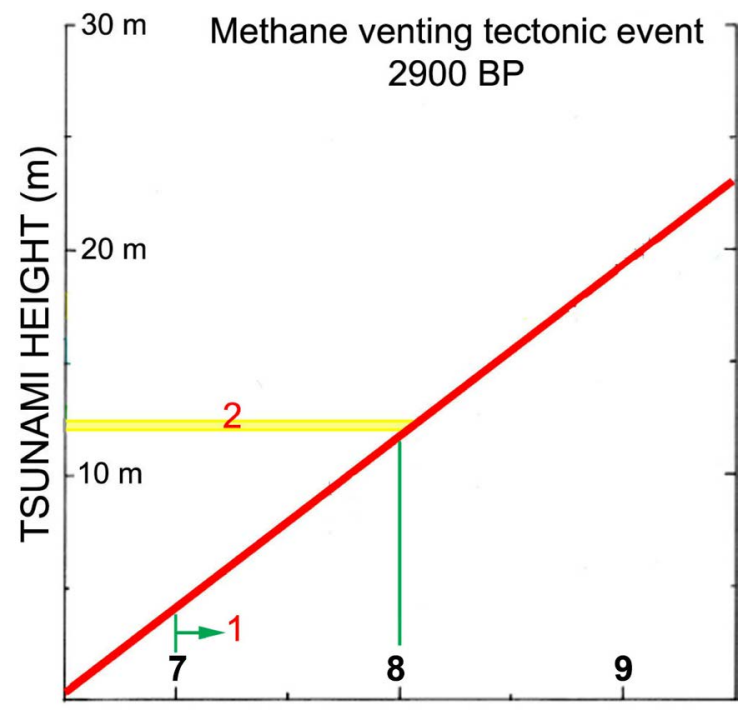

MAGNITUDE (Mw)

Figure 5. Comparing estimated earthquake magnitude equivalent (1) and observed tsunami wave height (2) of the methane venting tectonic event at 2900 BP [10] [14] [20], indicating that the ground shaking associated with methane venting tectonics may reach very high magnitudes comparable to $M 8.0$ earthquake magnitudes. A quite similar situation applies to the 3000 - $4000 \mathrm{BP}$ methane venting tectonic event documented south of Stockholm [20] [21]. 
timate according to Figure 1 relation between tsunami height and earthquake magnitude. It reveals that the $2900 \mathrm{BP}$ methane venting event set up a ground shaking comparable to a magnitude M 8.0 earthquake. This is, of course, quite remarkable because it seems to verify that methane venting tectonics imply ground deformations comparable to very high magnitude earthquakes.

\subsection{The 3000 - 4000 BP Methane Venting Tectonic Event}

A major methane venting tectonics event is recorded south of Stockholm [20]. It occurred sometime between 4000 and 3000 BP. The deformational structures indicate that the event must have been quite violent [20] [21]; a $25 \mathrm{~m}$ high cone of $150 \times 230 \mathrm{~m}$ width, and with gigantic blocks at the top. It seems that a tsunami event with a run-up of about $11-21 \mathrm{~m}$ can be associated with this event [10] [20]. The field data referring to the tsunami need to be revisited and checked before a serious magnitude estimate can be done. If an $11 \mathrm{~m}$ height is taken as wave height, we would be dealing with a ground-shaking magnitude of $\mathrm{M} 7.9$ by applying Figure 1 relations. The situation is quite similar to that of the 2900 BP event (Figure 5), in basic structure as well as in tsunami height.

\section{Discussion}

Figure 1 relations between tsunami wave height and earthquake magnitude [3] [4] implies an improved and simplified tool of converting observed tsunami wave height into corresponding earthquake magnitude as compared to preceding graphic relations [23].

Sweden has a database of 17 postglacial tsunami events [10] [12] [14]. The wave heights documented is consistent with a very high seismicity, not only in Late Glacial time, but also in Mid-Holocene and Late Holocene time (Figure 1).

Two paleoseismic events were selected for a test of the significance of Figure 1 relations established; viz. the $10,430 \mathrm{vBP}$ and the $9663 \mathrm{vBP}$ events, because both of these event were established by means of a multiple criteria [10] [11], besides they both represent very strong events with well-established tsunami heights. This implies the comparison between multiple independent parameters. The data referring to the $10,430 \mathrm{vBP}$ event are consistent with a mega-event of a magnitude of about M $8.5-9.0$ (Figure 3) and the data referring to the $9663 \mathrm{vBP}$ event to an event of magnitude of M 8.4 - 8.5 (Figure 4).

In the Late Holocene, there were two major tsunami events (Figure 1). Both of those events were generated by methane venting tectonics, however [10] [20]. Hence, there is no straightforward application of Figure 1 relations. In order to obtain some sort of quantification of the forces involved and magnitude of the ground shaking, Figure 5 was drawn. The tsunami height of the $2900 \mathrm{BP}$ event is consistent to a magnitude (rather magnitude equivalent) ground shaking of $\mathrm{M}$ 8.0, which seems to harmonize with the violence of the structures observed (Figure 5). The 3000 - 4000 BP event from the Stockholm area give a similar picture.

The process of methane venting tectonics [20] has by this (Figure 5) obtained 
a first serious quantification as to corresponding ground shaking, and both events were found to be consistent with a magnitude M 8.0 equivalent. This makes it a very dangerous factor for long-term stability and must be considered seriously in hazard assessment [5] [11].

\section{Conclusions}

A new tool for the conversion of observed tsunami heights to corresponding causation earthquake magnitude is presented (Figure 1).

It is quite successfully tested on multiple independent magnitude estimates from two paleoseismic events in Sweden (Figure 3, Figure 4). The general agreement is very good.

Methane venting tectonics is a novel process of severe bedrock deformation [10] [20]. Big tsunami events were generated at an event occurring $2900 \mathrm{BP}$ (the Skålboberget event in central Sweden) and at 3000 - 4000 BP (the Kvarnberget event in the Stockholm area). The tsunami heights documented correspond to an earthquake equivalent magnitude of about M 8.0 (Figure 5), indicating that methane venting tectonics implies violent deformation and ground shaking equivalent to high-magnitude seismic events.

\section{References}

[1] Mörner, N.-A. (2013) Tsunamis and Tsunamites: Origin and Characteristics. 4th International INQUA Meeting on Paleoseismology, Active Tectonics and Archeoseismology, 9-14 October 2013, Aachen, 165-168.

[2] Mörner, N.-A. (2018) Tsunami Deposits. In: Finkle, C., Ed., Encyclopedia of Coastal Science, Springer, Dordrecht. (In Printing)

[3] Lario, J., Bardaj, T., Silva, P.G., Zazo, C. and Goy, J.L. (2016) Improving the Coastal Record of Tsunamis in the ESI-07 Scale: Tsunami Environmental Effects Scale (TEE-16 Scale). Geologica Acta, 14, 179-193.

[4] Mörner, N.-A. (2016) Seismic Hazard Assessment: A Challenge for Science and Geoethics. International Journal of Earthquake Engineering and Hazard Mitigation, 4, 64-70.

[5] Fonseca, J.D. (2005) 1755 o terramoto de Lisboa-The Lisbon Earthquake. Argumentum.

[6] Stiros, S.C. (2010) The 8.5+ Magnitude, AD 365 Earthquake in Crete: Coastal Uplift, Topographic Changes, Archaeological and Historical Signature. Quaternary International, 216, 54-63.

[7] Polonia, A., Bonatti, E., Camerlenghi, A., Lucchi, R.G., Panieri, G. and Gasperini, L. (2013) Mediterranean Megaturbidite Triggered by the AD 365 Crete Earthquake and Tsunami. Scientific Report, 3, Article No. 1285. https://doi.org/10.1038/srep01285

[8] Mörner, N.-A. (2011) Paleoseismology: The Application of Multiple Parameters in Four Case Studies in Sweden. Quaternary Research, 242, 65-72.

[9] Mörner, N.-A. (1991) Intense Earthquakes as a Function of Glacial Isostasy. Tectonophysics, 188, 407-410.

[10] Mörner, N.-A. (2003) Paleoseismicity of Sweden-A Novel Paradigm. 16th International INWQUA Congress, Reno, 1-320. 
[11] Mörner, N.-A. (2013) Patterns in Seismology and Palaeoseismology and Their Application in Long-Term Hazard Assessment-The Swedish Case in View of Nuclear Waste Management. Pattern Recognition in Physics, 1, 75-89. https://doi.org/10.5194/prp-1-75-2013

[12] Mörner, N.-A. and Dawson, S. (2011) Traces of Tsunami Events in Off- and on-Shore Environments. Case Studies in the Maldives, Scotland and Sweden. In: Mörner, N.-A., Ed., The Tsunami Threat: Research and Technology, InTech, Rijeka, 371-388. https://doi.org/10.5772/13686

[13] Mörner, N.-A. (2013) Drainage Varves, Seismites and Tsunamites in the Swedish Varve Chronology. GFF, 135, 308-315. https://doi.org/10.1080/11035897.2013.764546

[14] Mörner, N.-A. (2016) Tsunamis in Sweden: Occurrence and Characteristics. In: Mokhtari, M., Ed., Tsunami, Chapter 6, InTech, Rijeka, 115-133. https://doi.org/10.5772/63956

[15] Mörner, N.-A. and Sun, G. (2008) Paleoearthquake Deformations Recorded by Magnetic Variables. Earth Planetary Science Letters, 267, 495-502.

[16] Mörner, N.-A. (1995) The Baltic Ice Lake-Yoldia Sea Transition. Quaternary International, 27, 95-98.

[17] Björklund, A. (1990) Methane Venting as a Possible Mechanism for Glacial Plucking and Fragmentation. GFF, 112, 329-333.

[18] Mörner, N.-A. (1993) Methane Dehydration Tectonics. Bulletin of the INQUA Neotectonic Commission, 16, 71-72.

[19] Sjöberg, R. (1994) Bedrock Caves and Fractured Rock Surfaces in Sweden: Occurrence and Origin. PhD Thesis, Stockholm University, Stockholm, Vol. 7, 1-110.

[20] Mörner, N.-A. (2017) Methane Hydrate in Crystalline Bedrock and Explosive Methane Venting Tectonics. Earth Science Review. (In Press)

[21] Mörner, N.-A. (2017) Supplementary Material to: Methane Hydrate in Crystalline Bedrock and Explosive Methane Venting Tectonics. Earth Science Review. (In Press)

[22] Mörner, N.-A. (2016) Methane Venting and Methane Venting Tectonics. 13rd International Conference on Gas in Marine Sediments, Tromsø, 19-22 September 2016. https://www.researchgate.net/publication/308306076

[23] Silva, P.G., Rodriguez-Pascual, M.A., Perez-Lopez, R., Bardaj, T., Lario, J., Alfaro, P., Martinez-Diaz, J.J., Reicherter, K., Gimenez, J., Giner, J., Azañon, J.M., Goy, J.L. and Zazo, C. (2007) Catalogacion de los efectosgeologicos y ambientales de los terremotos en España en la Escala ESI. 2007 y suaplicacion a los studio paleoseismlogicos. Geo-Temas, 10, 1063-1066. 
Submit or recommend next manuscript to SCIRP and we will provide best service for you:

Accepting pre-submission inquiries through Email, Facebook, LinkedIn, Twitter, etc. A wide selection of journals (inclusive of 9 subjects, more than 200 journals)

Providing 24-hour high-quality service

User-friendly online submission system

Fair and swift peer-review system

Efficient typesetting and proofreading procedure

Display of the result of downloads and visits, as well as the number of cited articles Maximum dissemination of your research work

Submit your manuscript at: http://papersubmission.scirp.org/

Or contact ojer@scirp.org 